\title{
Weaknesses Of Judges Thinking In Civil Law Systems
}

\author{
Made Hendra Wijaya \\ Faculty of Law, Universitas Mahasaraswati, Denpasar-Indonesia \\ hendrawijaya@gmail.com
}

Published: 25/02/2021

How to cite:

Wijaya, M. H. (2021). Weaknesses Of Judges Thinking In Civil Law Systems. Sociological Jurisprudence Journal. 4(1). Page 39 - 44. https:// doi.org/10.22225/scj.4.1.1834.39-44

\begin{abstract}
Judge's an instrument of justice that are at the forefront in enforce the justice in society, but sometime the judge's decision does not represent justice in society, because the judge's in conducting the trial should follow existing the systems. Just as judge's as adherent of the civil law system. In this paper describes the civil law system, started from Roman era, German, Francis, as well as elements of a definition of the civil law systems, and then discusses the judges in the civil law system, and discuss any weaknesses civil law2 judges in terms of implementing the trial in finding justice in society.
\end{abstract}

Keywords: Judge's; Civil Law System; Weaknesses

\section{INTRODUCTION}

Judges as law enforcers are at the forefront in upholding justice in society, where currently judges are required to realize a sense of justice in the community. However, many people do not trust the performance of judges to obtain justice, this is due to the judge's decision which is sometimes considered unsatisfactory for both parties to the case.

Indeed, the judge in issuing a decision in a case, wants to be able to satisfy both parties in a litigation, and try to make the fairest decision, but this is not easy to realize, because the judge in carrying out justice, and in making decisions always must follow the systems and procedures established by the state and the law.

Likewise, if a state is an adherent of the civil law system, the judge in carrying out his duties must follow the procedures and mechanisms of the court in accordance with the civil law system, as we know, that the civil law system is an adherent of positivism ie all the administration of the state and justice must be based on Act. So that in the court process the judge will be very difficult to decide on a case in accordance with a sense of justice that continues to grow, while the law that becomes a role model cannot follow the development of justice desired by the community.

In addition, the values and culture of the community are different and have their own characteristics, which is a reflection of the will of the community itself. Meanwhile, in the civil law system, judges must follow the law and the principle of legality, and the law must be formed by the legislative body, which in the civil law system the power of law making is in the hands of the legislature and institutions that respond to public interests (popular willa) ${ }^{1}$.

\section{RESULT AND DISCUSSION}

\section{Civil Law System}

Civil law system that is commonly used by countries adhering to the Continental European system.

1. Ade Maman Suherman, 2004, Pengantar Perbandingan Sistem Hukum, civil law, common law, hukum islam, Cet. Pertama, P.T Raja Grafindo Persada, Jakarta. p. 12 
Civil law is a term taken in civil law in the Justianian era named Corpus Juris Civilis (529-34 AD) based on direct guidance from Emperor Justinian, consisting of 4 parts, namely:

1. Codex, The first Codex ${ }^{2}$ (7 April 529 AD) is a codification of decisions before Emperor Justinian, then the second Codex (early $534 \mathrm{AD}$ ) is a new edition of Codex that fixes the old Codex

2. The Digest ${ }^{3}$ (December 16, $533 \mathrm{AD}$ ), is a core collection of opinions from contemporary legal experts on classical law and contains improvements to Code 534, where this Digest contains thousands of legal propositions to provide legal force;

3. The Institutes $^{4}$ (December 31, $533 \mathrm{AD}$ ), is a text book for law that is used as an introduction by novice law students, because Digest is very difficult to learn by novice law students;

4. The Novellae $e^{5}$ (535-555 AD), is a new literature and law that contains the field of administration and church law, and also many changes to private law, especially in family law.

In addition, Corpus Juris Civilis Roman in the era of Justinian rule, there is another Civil law root, the Canon Law of the Roman Catholic Church that emerged in the twelfth century, which was an ecclesiastical court developed within the Roman Catholic Church, which contained clerical matters, legal sources, marriage, and regarding punishment (punishment). In addition, ecclesiastical courts introduce methods for the documentation process, legal arguments by the parties, and legal reasons as the basis for all decisions ${ }^{6}$.

Then, in the medievel period there was the Lex Mercatoria or commercial law which is a variation of the law that emerged from the Italian Peninsula commercial fields and other ports in the Mediterranean sea area. Meanwhile, each city code varies, the Barcelona Consolata Del Mare which is translated into Latin, French and Italian and spread throughout Europe, and this law becomes influenced in the region ${ }^{7}$.

In the enlightenment period there was a French state led by Napoleon Bonaparte, a pioneer in the development of modern civil code and the spread of the countries he conquered.In 1800, he set four different lawyers, They met about 100 times in four years, producing a civil des Francais code (Napoleon Code) in 1804 consisting of three books and 200 more articles. The basic structure of the Napoleon Code is as follows: General Principles: Publication, application and effect; Book I (articles.7515): status of people, marriage, divorce, and father line; Book II (articles 516-710): real and personal property: Book III (articles.711-2281): contracts, losses and security interests ${ }^{8}$.

Then, in 1873 a German commission was created to bring about a uniform civil code to just unify the German state. The comprehensive Burgerliches Gesetzbuch was recognized in 1896, and was used on January 1, 1900. The basic structure of the Burgerliches Gesetzbuch is as follows: Book I: General principles, definitions, periods giving instructions or provisions, and classification of legal actions; Book II: Contracts and losses; Book III: real and personal property; book IV: family law includes marriage; and book V: series of laws, wills, and others 9 .

Sn addition, the civil law system also gained general influence, modification and improvement in the twentieth century, namely the existence of a Constitutional court in Austria in 1920, where the state of Austria introduced to the European Continent a permanent system of centralization of judicial review which utilized a specialized constitutional court . The centralized system of constitutional review gives power to show constitutional issues. The specialization of the Constitutional Court is generally considered to be formally outside the judicial system for reasons that will be explained below ${ }^{10}$.

Then there is the De-codification of the complexity of the twenty lives, certain trades, which have led to whether something is shown to be a "decoding" of civil law, which has several things namely:

1. Reproduction of additional specialization of the Act, such as worker code;

2. Olga Tellegen and Corperus, 1993, A Short History Of Roman Law, Routledge 11 New Fetter Lane, London, p.141

3. Ibid

4. Ibid p. 144

5. Ibid p. 146

6. James G. Apple and Robert P. Deyling,1995, A Primer on the Civil Law System, FEDERAL JUDICIAL CENTER, available online at http://www.fjc.gov/public/pdf.nsf/lookup/CivilLaw.pdf/\$file/CivilLaw.pdf, diakses pada 27 Januari 2015

7. Ibid, p. 10-11

8. John Bell, Sophie Byron, dan Simon Whittaker, 1998, PRINCIPLES OF FRENCH LAW Oxford University Press. p, 23-24.

9. James G. Apple and Robert P. Deyling,. Lok Cit. p, 15-16.

10. Herbert Hausmaninger. 1998, THE AUSTRIAN LEGAL SYSTEM, Kluwer Law International. p. 127-145 
2. Delegation of authority for the executive branch; and

3. Judge-making laws, such as the case of loss / jurisprudence of consumer protection in France and Germany

In short, legal knowledge or positivism which calls for the creation of the codes, which is to cover up all the conditions that can be thought of, provides a way for practicality from modern life, following the areas of expertise of the law to develop out the traditional mechanisms of overall codification.

In addition the Council of Europe (CoE) was formed in 1949 and accompanied international jurisprudence under the European Convention on Human Rights which had had a dramatic influence on the development of human rights law in Member States. Council of Europe (CoE) members reaching out to Europe and the former Soviet Union are considering complementary geography between two different multilateral organizations.

Then the formation of the European Union Since 1957, namely to accompany the supranational and jurisprudential laws which have had a strong effect on the elements of domestic law in Member States, which now include all common Western European countries based on the Continent's legal traditions. Derived from his notes is the fact that the European Union includes countries which do not follow European Continent traditions, so the process of developing supranational Laws that they can all agree on serving for the purpose of harmonizing variations of legal traditions in a number of regional differences the region.

The elements of the definition of civil law are ${ }^{11}$ :

1. Public Law versus Private Law: A conceptual difference that forms the architecture of the civil law system. In public versus private law there are differences as follows:

- Private Law: the only function of government is to recognize and provide for the exercise of individual rights (private). For example this will be a commercial code and a civil code; and

- Public Law: a state that acts to protect and promote public interests. An example of this would be administrative law, constitutional law, and criminal law.

- Then when viewed from the legal structure, the court systems generally use this public-private difference. "Ordinary courts" take private law and the basis of the field of public law from criminal law. The realization of the "Administrative court" takes other areas of public law. Legal education and general practice divide on the same lines.

2. Codes and Case-Law: civil law lawyers look at codes and explanations more than cases, and the doctrine of the decision view (case-law precedent) does not constitute use:

3. Legal Education System: civil law is a student who has not yet received a degree that has a very different format from the U.S. post-graduate legal education or U.K - style of student programs that have not yet received a degree. One special feature of several civil law systems is the presence of a Masters School. These programs are designed to provide specialized training for potential judges and potential public prosecutors. The term magistrate is to give a broad understanding in the same origin as France, namely the magistrate, which shows lawyers who take state offices including ordinary judges and ordinary public prosecutors. Ordinary judges will always confer with administrative judges in the French system.

4. Maybe those who know well, can be seen for example from the Masters School is the French National Legal Service College, or the Ecole nationale de la Magistrature, in Bordeaux. At the french entrance for Ecola is through an open competitive process. Which is guarded by French pressure on judges as civil servants, personnel with 5 years of civil service followed for competition with lawyers, legal scholars, law lecturers for judicial opening. The success of the participants in a 31 month course that involved both training and internships. On completion of this training the judge sets out for an "ordinary" court. Determination is clever through a Presidential Decree based on recommendations from the Minister of Justice and with the approval of the High Council of Judges and State Public Prosecutors ${ }^{12}$.

11. Scott N. Carlson, 2009, Intro To Civil Law Legal Systems (INPROL), International Network To Promote The Rule Of Law, www.inprol .org.

12. Christian Dadomo \& Susan Farran, 1996, THE FRENCH LEGAL SY STEM, sweet \& maxwell, p. 17 
5. Legal profession: Civil law lawyers often choose certain professional focal areas during or at the end of their law school, and they rarely replace the professional part later in their careers. Each of these topics is checked down.

\section{Judges That Follow The Thoughts Of The Civil Law System}

In Indonesia, the term judge can be seen in the Act of the Republic of Indonesia Number 48 of 2009 regarding Judicial Power, In Indonesia the term Judge can be seen in the Law of the Republic of Indonesia Number 48 of 2009 concerning Judicial Power, namely in Article 1 paragraph 5, which states that a judge is a judge in the Supreme Court and a judge in a judicial body below him in the general court environment, religious court environment, military court environment, state administrative court environment, and judges in special courts within that court environment.

In the case of an examination, trial and adjudication court case with a composition of a panel of at least 3 (three) judges, unless the Law determines otherwise, it can be seen in Article 11 paragraph 1 of the Law of the Republic of Indonesia Number 48 of 2009 concerning Judicial Power. Likewise in France, that French law embodies the principle of collegiality ${ }^{13}$. In general there are three judges, whose function is to listen and participate in negotiations in deciding cases. Because a state is a civil law follower, it is also automatically a follower of positivism which has reduced the notion of law to a narrower space, namely the Law (statute), then the source of law in the civil law system is statute, regulation, and customs. Statutes are laws, regulations are regulations whose actions have been passed through the legislative power of the legislature and executive. Meanwhile, Customs are habits, where customs are not an appropriate legal term in the world of positivism, customs which are habits that are practiced in society that are not poured into written form (non statory law), customs as a source of civil law, namely with the condition of habit it is a legal representative with a record or reserve that there are no statutes and regulations that conflict with it ${ }^{14}$.

In addition, in the civil law the role of the legislature is very important, namely making laws, while the courts in the civil law judge only acts as the application of the law, not as a legislator. This is like the views of Montesquieu and Kant, who argued, according to the classical view, the judge in applying the law to concrete legal events did not carry out its role independently ${ }^{15}$. So in the civil law system the role of the judge is only as a mouthpiece or mouthpiece of the law (buche de la loi), so it cannot change the strength of the law, cannot add and or reduce it.

In the civil law system, Yurusprudensi is not the main source of law, only to apply general principles, and their explanation through secondary laws, so that the Law takes precedence over jurisprudence in resolving cases ${ }^{16}$. Then in appointing judges in the civil law system, judges are appointed and selected from law schools that have just fresh graduated with certain specialists ${ }^{17}$.

Civil law judges are influenced by Rousseau's theory, ie, that the state is the source of all rights under the social contact, while English judge favour Hobbes' theory that the individual agreed to porfeit to the state only certain rights ${ }^{18}$.

Civil law judges apply standardized court hearings, and crystallize the principles of civil law, which are usually colored by rigid doctrines. While the function of the doctrine in the cuvil law system is to describe or explain the inorganization of cases, books and legal dictionaries, rules, principles that will explain an object with impure elements. Thus, it will direct the practice and court to provide solutions to certain cases in the future.

\section{Weaknesses Of Judges Thinking Civil Law Systems}

In a book entitled "The Civil Law Tradition", written by Merryman, a legal comparative expert, he stated that career judges (born in the civil law system) tended to have a bureaucrat mentality, lacked self -confidence and independent thinking. This results in them tending to be hesitant or afraid to make controversial decisions and have a large political impact. This is different from judges in countries that

\footnotetext{
13. P. Gonod et L. Cadiet (eds) 2009, Le Tribunal des conflits, Dalloz,.Paris

14. Suherman, Ade Maman, Op cit, p, 18

15. Mertokusumo, Sudikno 2004, Penemuan Hukum Sebuah Pengantar, Liberty, Yogyakarta, p. 40-43

16. Kamil. H. Ahmad dan Fausan, M, 2008, Kaedah-Kaedah Hukum Yurisprudensi, Kencana Prenada Media Group, Jakarta. p. 43

17. Suherman, Ade Maman. p. 122

18. Rousseau and Hobbes, 1992, theories are compared in Y. GUCHET, la pensee Politique,, Armand Colin, Paris, p. 56-60
} 
adhere to the Common Law system, which before becoming a judge usually worked as lawyers, public officials, or academics ${ }^{19}$.

Civil law judges will be more inclined to carry out their duties in adjudicating according to the sound of the Law, or as a mouthpiece or mouthpiece of the Law, which means the judge's decision only represents justice based on the Law, not adjudicating based on justice felt in the community. The error will be seen if the judge only decides based on the Law, that is, if the article in the Act is not in accordance with the values of Human Rights, Freedom, Togetherness, and does not look at human dignity or is far from the value of justice in society, still the judge's decision cannot be blamed because it is in accordance with applicable laws.

That is as stated by Jerome Frank, who exemplifies the words of Jastrow, "Instead of the answers in the book that happened to be wrong, most students in the class succeeded in answering the questions the young mathematician will work out how to get the answers needed by the book, even though it is a very mathematical process" ${ }^{\prime 2}$. Of course, sometimes judges adhering to civil law in deciding a case in court must oppose their conscience because they have to follow laws which are sometimes not in accordance with the feelings of justice from the community.

In addition, civil law judges can blame the Law because their decisions are not in accordance with the existing justice in the community, because they can reason that they have conducted trials and made decisions in accordance with the mandate of the Law, which is in accordance with the justice Act. Then in the civil law system, because the law takes precedence over jurisprudence, causing the legal discovery by judges will run slowly in the civil law system

Weaknesses of civil law judges can also be seen in the system of appointment of judges, namely the appointment of judges who are appointed and chosen from law schools that are fresh graduated with certain specialists. Which is the weakness of judges can be seen based on the quality of individual judges, because the chosen ones are still fresh graduated, of course, these young judges do not have more experience in handling a case, and are affected by individual judges' emotions in conducting a trial.

\section{CONCLUSION}

Weaknesses of civil law judges are seen by judges to be too obedient or follow what is contained in the Law, so that sometimes the judges 'decisions are not in accordance with justice in the community, but the judges' decisions are more representative of the justice of the Law. In addition, weaknesses of civil law judges will be late in terms of legal discovery, because the law is the main thing in the civil law system, due to the fact that jurisprudence is not the main but the law is the main in the civil law system, and the recruitment and appointment system of Civil law judges selected from law schools who are fresh graduated with certain specialists, making judges' decisions will be affected by the emotionality of individual judges in conducting trials.

It can be asked from this paper that judges in deciding a case in the civil law system need progressive thinking so that justice can be created in the decision.

\section{REFERENCE}

Ahmad, K. H., \& Fausan, M. (2008). Kaedah-Kaedah Hukum Yurisprudensi, Jakarta: Kencana Prenada Media Group.

Apple, J. G., \& Deyling, R. P., (1995) A Primer on the Civil Law System. Federal Judicial Center. Retrieved from https://www.fjc.gov/content/primer-civil-law-system-0

Argama, R. (2006) Makalah Tanggung Jawab Profesi Hakim Sebagai Aktor Utama penyelenggara Kekuasaa Kehakiman Di Indonesia. Fakultas Hukum Universitas Indonesia.

Bell, J., Byron, S., \& Whittaker, S. (1998). Principles Of French Law. Oxford: Oxford University Press.

Carlson, S. N. (2009), Intro To Civil Law Legal Systems (INPROL). International Network To Promote The Rule Of Law. Retrieved from https://www.fjc.gov/sites/default/files/2015/Introduction\%20to\%20Civil\%20Law\% 20Legal\%20Systems.pdf

Dadomo, C., \& Farran, S. (1996). The French Legal System. Sweet \& Maxwell

19. Ibid

20. Jerome Frank, 2013, Hukum \& Pemikiran Modern, Nuansa Cendana, Bandung, p.157. terjemahaan dari Jerome Frank, 1963, Law and The Modern Mind, Anchor Books Donbeday \& Company, Inc,. New York. 
Frank, J. (2013). Hukum \& Pemikiran Modern. Bandung: Nuansa Cendana.

Gonod, P. (2009). Le Tribunal des conflits. Paris: Dalloz.

Hausmaninger, H. (1998), The Austrian Legal System. Kluwer Law International.

Mertokusumo, S. (2004). Penemuan Hukum Sebuah Pengantar. Yogyakarta: Liberty.

Rousseau \& Hobbes. (1992). Theories are Compared in Y. GUCHET, la pensee Politique. Paris: Armand Colin.

Suherman, A. M. (2004). Pengantar Perbandingan Sistem Hukum, Civil Law, Common Law, Hukum Islam, Cet. Pertama. Jakarta: P.T Raja Grafindo Persada.

Tellegen, O., \& Corperus. (1993). A Short History Of Roman Law. London: Routledge 11 New Fetter Lane. 